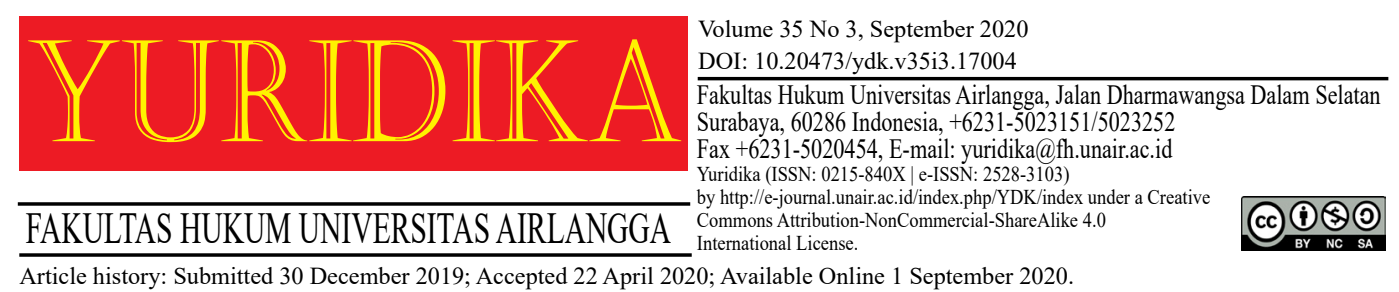

\title{
Sister Ship Binding Clause as a Reinforcement of Debt Repayment Legal Certainty on Ship Mortgage
}

\author{
Fani Martiawan Kumara Putra \\ fanimartiawan@gmail.com \\ Wijaya Kusuma Surabaya University
}

\begin{abstract}
The field of marine transportation plays a role that is not less important than land transportation in terms of economic development in Indonesia. As a result of globalization, business activity continues to increase, whether it is business in the field of marine transportation or outside the field, it is certainly undeniable that the activity requires a very large funds, which funds can be obtained by one way is to apply for credit/loans. Large amount of loans will only be given with the imposition of collateral as a further process. The imposition of collateral for large amount of loans may designate the ship as its collateral object by utilizing the Mortgage security agency. However, when the ship is being vetted on a voyage across national borders, the impact is when its debts mature, then the execution of such ship will be difficult, caused by the inadequate legal rules in Indonesia, and not all countries ratify the ship's arrest convention. This study aims to provide a solution in order to achieve legal certainty of Mortgaged object execution that being across national borders for a significant development of shipping business. This research is normative research. The result obtained is the need of a clause in the Mortgage security document concerning the binding of sister ship with equal value, as the collateral object backup, when the execution of ship loaded with Mortgage security is unable to be done since it is located outside the state border.
\end{abstract}

Keywords: Mortgage, Sister Ship, Legal Certainty; Execution.

\section{Introduction}

Indonesia straddles the Equator between the Indian Ocean and the Pacific Ocean. Indonesia's many tourism resources make Indonesia an excellent tourist destination. For example, Indonesia has abundant cultural heritage, and natural resources, throughout the country. It has pristine and virgin tropical forest and an authentic heritage. Therefore, Indonesia promotes and markets itself as Wonderful Indonesia, and the slogan is quite true, although not necessarily always in good 
ways. The beautiful natural resources of Indonesia are a major concern for the government to promote and market Indonesia to potential tourists, to increase it economy aspect. Indonesia offers an attractive, authentic and wonderful tourist destination, which differs from what other countries in particular western countries, can offer. This sentence promises that Indonesia is known for its variety of wonderful places, which are rich in natural beauty, whether under the sea, in the beautiful mountains, or the tropical forests. ${ }^{1}$

The effort to increase it economic aspect is a thing that needs to be done since the pattern of business transactions in the world is demanded to be increasingly developed on the basis of the existence of globalization that has an influence on the world market. The modern challenges of globalization have affected the financial sector as well. Crisis phenomena emerge on a frequent basis. ${ }^{2}$ One indicator of changes in world markets is economic growth. Economic growth as one of the supporting developments in a country, demands the need to take several steps so that the expected elements of economic growth are successful, and the sources of development funds are increasing. Along with the development of the era and the development of increasingly advanced technology, as well as world economic growth that is so fast, demanding business players in Indonesia to be able to compete for the continued existence of their business. Therefore, the Vice President of the Republic of Indonesia affirms that at present the government has implemented the three pillars of strategy aimed at increasing competitiveness and increasing the number of industries in Indonesia. As country rich in natural resources, Indonesia should be able to develop the processing industry so that it can be utilized as efficiently as possible. The three pillars of the Vice President are:

\footnotetext{
1 Muhammad Arfin Muhammad Salim, 'Authenticating the Tourist Destination on the Official Tourism Website of Indonesia: A Multimodal Perspective' (2018) VI Astra Salvensis (Supplement no. 1).[338].

2 Imeda Tsindeliani, 'Financial Law as a Public Law Branch: A Fresh Look at the Signs of Publicity' (2019) 22 Journal of Legal, Ethical and Regulatory Issues < https://www.abacademies.org/ articles/financial-law-as-a-public-law-branch-a-fresh-look-at-the-signs-of-publicity-8677.html>.[2].
} 
1. Indonesia no longer sells raw materials to the world market. This strategy is followed by a downstream program to increase added value;

2. Growing the domestic industry to create equality and create new jobs;

3. Being part of the global supply chain. ${ }^{3}$

One form of adaptation for business people, is by developing the company. In order to realize this development, of course, business people in a need of capital, while the capital needed is not a small capital, but often what is needed is capital in large amounts, solely for the continued development of the quality of their business and/or economy.

This means that to be able to meet the needs of business people in the economic field, it is necessary to have adequate facilities and infrastructure, so that economic activities may run smoothly and the profit gained will be increased and be able to compete in the midst of such rapid global economic growth. One form of facilities and infrastructure is of course the field of credit or financing. Credit or financing is a concrete manifestation of the form of financial support for business people who need loan funds to expand, improve and maintain the balance of their business. Thus, the presence of this credit institution has a very important role in economic activities and growth and development in the current era. Financing institutions are currently more often used for registered movable objects such as cars and motorbikes, while for business development, credit institutions are more often used. Credit institutions can be in the form of Banks or Non-Banks, but at this time, credit institutions that are often used are Banks.

Banking is a bridge for the real sector finance, both in the context of improving business and investment climate, also in terms of job creation. ${ }^{4}$ Discussing about the credit carried out by the Bank, of course, will discuss the money traffic, where credit activities will in and out, not only low value, but also very high value. To maintain the health of these credit activities, the credit should also be accompanied

\footnotetext{
3 Soeling Pantius D, 'Enhancing Regional Competitiveness Through Village Owned Enterprise in East Priangan Indonesia' (2018) VI Astra Salvensis (Supplement no. 1).[724].

4 Gabrielia Febrianty Shofiana and Abd. Shomad, 'Transformation of Banking Law in Indonesia' (2019) 19 Jurnal Dinamika Hukum.[430].
} 
by security, this is intended to provide legal security and certainty in the provision of credit, both for those creditors or the debtor.

This security is one form of the precautionary principle that must be applied by the Bank as a credit institution, regulated in Law No.7 of 1992 concerning Banking, as amended by Act No.10 of 1998 concerning Banking (hereinafter referred to as Banking Law) Article 2 confirms that Indonesian Banking in its business is based on economic democracy using the principle of precautionary. The precautionary principle is further regulated in Article 29 paragraph (2) of the Banking Law which stipulates that Banks are required to maintain Bank soundness in accordance with capital adequacy, asset quality, management quality, liquidity, and profitability, solvency and other aspects related to Bank business, and must carry out business activities with this precautionary principle. The Bank's prudential principle in practice is realized in the form of 6C, namely Character; Capacity; Capital; Collateral, Condition of Economy, and Constraint.

Regarding credit matters as above, what needs to be considered is the collateral aspect, which means the security of the credit. As the name implies, namely collateral, it is necessary to have an object or object that will be secured to convince and obtain funds from the creditor. Besides that, it is also necessary to pay attention to the security institution, considering that later the procedural provisions of this security institution will determine whether the security process is valid or not. The security institution itself has actually been known since the existence of Burgerlijk Wetboek (hereinafter referred to as BW). This security institution is very related to the classification types of objects, which in BW, objects can be classified into 6 (six) kinds, and one of the most important classification forms is movable and immovable objects. The importance distribution of movable and immovable objects is related to Bezit (Article 1977 BW), Bezwaring (Article 1150-1232 BW), Levering (Article 612, 613, 616 BW), Beslag (Article 197 HIR), and Verjaring (Article 610 jo. 1946, 1963, 1969 BW).

Bezwaring (security) in the case of movable and immovable objects became the basis for the division of the security institution. For movable objects, the security 
institution can use Gadai (regulated in Article 1150-1160 BW), or with Fidusia (regulated in Law No. 42 of 1999 concerning Fiduciary). For non-movable objects not related with land, the security institution available is Mortgage (regulated in Article 1161-1232 BW as the very base law), whereas for immovable objects in the form of land rights, the security institution is Hak Tanggungan (regulated in Law No. 4 of 1999 Regarding Underwriting Rights on Land and Objects Related to Land. Regarding to the credit, and security institutions, the parties are known as debtors (as parties who are obliged to carry out achievements) and creditors (as parties who are entitled to achievement).

As a form of business activity that contributes to developing Indonesia's economy, it is in the field of sea transportation, namely the shipping business. Shipping business in Indonesia is a promising business, because considering that the territory of Indonesia consists mostly of the oceans, this is because Indonesia has two-thirds of the sea area compared to all the islands in Indonesia. Indonesia is known as a maritime country, and its position as an archipelagic country, making sea transportation as one of the important aspects of economic development in Indonesia. Not spared from the demands of the development of the company, shipping or shipping business players also need substantial capital to improve the quality of their business, which can be facilitated by credit activities with the ship as the object of security. As the security institution, Mortgage insurance institutions can be used (when the ship is registered) or use a Fidusia security institution (when the ship is not registered in Indonesia).

Mortgage Security can now be said to be the security institution that is mostly needed, and in demand by the public who run sea transportation business. Mortgage is currently regulated in Law Number 17 of 2008 concerning Shipping (hereinafter referred to as the Shipping Law), and the Minister of Transportation Regulation No. 39 of 2017 concerning Ship Registration and Nationality (hereinafter referred to as PERMENHUB Ship Registration). However, as stated earlier, the facilities and infrastructure must be adequate and support the economic progress, especially in the credit aspect. Even though in fact that the Mortgage regulation above has been 
confirmed about legal protection for creditors and debtors, in practice, security with Mortgage institutions will encounter problems when it come to the security object execution step when the debtor has been assessed as default. Disputes can be settled through dispute settlement mechanism. With the increasingly widespread business transaction activities, disputes between parties involved is inevitable. Each dispute that occurs always demands a quick solution and resolution. ${ }^{5}$

As per Article 224 HIR jo. Article 60 paragraph (4) Shipping Law jis. Article 31 paragraph (3) PERMENHUB Ship Registration, given to the creditor the form of the right of execution of the ship which is subject to the Mortgage. First, by utilizing the executorial title contained in the Ship Mortgage Deed Grosse. Secondly, is through Article 1178 paragraph (2) BW, which is given the right to the ship Mortgage holder (creditor) to carry out execution through the Parate Executie institution by stating the Eigenmachtige Verkoop clause (which in practice is included in the Power of Attorney for Installing a Mortgage (hereinafter referred to as SKMH)). Execution Ship Mortgages can only be done in these two ways.

Execution of Ship Mortgages collateral objects as a form of creditors protection in the settlement of credit, encounter problems and cannot be implemented when the object is outside the jurisdiction of Indonesia. This situation is due to a legal vacuum in Indonesia to place execution seizures and carry out executions of Indonesian ships that are outside the jurisdiction of Indonesia. This legal vacuum is caused by Indonesia not ratifying the 1999 Arrest of Ships Convention. Meanwhile, not all countries can ratify the 1999 Arrest of Ships Convention, because there is a clause in the Convention that could endanger the sovereignty of a State. This legal vacuum can of course also affect the international shipping business.

Based on the background above, the problem that will be discussed in this paper is the solution to the limited ability to execute Mortgage object when the Mortgage object is outside the jurisdiction of Indonesia, by using sister ship. This

\footnotetext{
5 Anita Afriana and Efa Laela Fakhriah, 'Understanding the Plurality of Consumer Dispute Resolution in Indonesia: A Comparative Study with Singapore' (2019) 34 Jurnal Yuridika <https://ejournal.unair.ac.id/YDK/article/view/9091>.[2].
} 
research is a normative research, which means the findings and discussion done in this research are based on Indonesian law regulation, and the problematic are caused by the lack of Indonesian law regulation. This research is not based on social respond that came from a law regulation.

\section{Legal Certainty of Ship Mortgage}

The security is essentially a matter agreed upon in an agreement and used to provide a safe condition for a party. The object of the security can be in the form of an object and can also be a person. In the case of debts when the object of the security is a person, of course the main condition is that the person who is the guarantor is able to pay off the debtor's debt when the debtor is truly unable to repay the debt. Whereas when the object of the security is an object (known as a material security), then of course the main requirement is that the object must have economic value and may be transferable, as implied in Article 1131 BW.

It cannot be denied that the loan security as above will often occur as one of the consequences of the engagement that was born of the debt agreement in the community, therefore a legal institution that contains norms regarding this loan security is needed. The Lawmaker provides a way out with the Security Law. The security law is a legal institution that regulates the imposition of collateral as a follow-up to the debt agreement, which covers both the arrangement of personal security as well as material security, with the aim of providing assurance to the creditor that the debt will be repaid, so that the debtor is easier to obtain credit facilities.

The current security law regulation in Indonesia is spreaded, considering that there are several security institutions recognized in Indonesia, which are then regulated in separate laws. As one of the easiest identification methods, the Security Law regulation is set in BW and outside BW. Set in BW is in Book II BW and outside Book II BW (in Book III BW), while the one set outside BW is compiled in a separate Law. The most widely spread arrangement, and no unification until now, is the arrangement of Mortgage Security. 
In order to be used as a Mortgage object, the ship must be registered in advance, the redaction of Article 314 Wetboek van Koophandel asserts that for a ship to be registered, it must have a minimum weight of $20 \mathrm{~m} 3$ (twenty meters cubic). The limitation on the size of the ship that can be distributed has been amended by the provisions of Article 158 of the Shipping Law which confirms that ships that can be registered are those with a weight of at least 7GT (gross tonnage). Article 60 of the Shipping Law confirms that if a ship has been registered and will be used as collateral, the Mortgage Security institution can be used. Based on Article 1 number 12, Article 158 and Article 60 of the Shipping Law, the elements listed in the ship Mortgage are:

1. The existence of material rights;

2. The object is a ship that has a minimum weight of $7 \mathrm{GT}$;

3. The ship must be registered;

4. Given an authentic deed;

5. Ensure debt bills.

Mortgage as a material security, has several special characteristics, the nature of Mortgage is explained by Kartini Muljadi in his book, including: ${ }^{6}$

1. Mortgages are compelling (absolute);

2. Mortgage can be switched or transferred;

3. Mortgages are individualized;

4. Mortgages are comprehensive (totaliteit);

5. Mortgages cannot be separated (onsplitsbaarheid);

6. Tiered Mortgage (there is one priority over the other);

7. Mortgages must be announced;

8. The Mortgage follows the object (droit de suite) in Article 1136 paragraph (2), and Article 1198 BW;

9. Droit de preference in Article 1132 BW;

10. Mortgage as Jura in Re Alinea (limited).

The next principle is the Principle of Speciality, namely the binding of a Mortgage can only be done on objects specifically designated.

Mortgages as collateral institution involving objects, require the existence of special objects that are bound as collateral in the loan agreement. Ship Mortgage 6 Kartini Muljadi and Gunawan Widjaja, Hak Istimewa, Gadai Dan Hipotek (Kencana
2005).[207]. 
could be placed for ships that can be directed at ships, fishing ship, also river and lake water sailing ships, this is based on Article 6 paragraph (1) PERMENHUB Ship Registration which confirms that the registration of ownership rights on ships is divided into 3 (three) categories: (a). ship; (b). fishing ship; and (c). ships sailing in rivers and lakes. This means that Mortgages can be charged to ships, fishing boats, and ships sailing in rivers and lakes. PERMENHUB Ship Registration determines that the ship can be registered in Indonesia by the owner to Pejabat Pendaftar dan Pencatat Baliknama Kapal (Article 2 paragraph (2)), at the work unit in the field of registration and nationality of ships at the Directorate General of Sea Transportation or the port of registration of ships as mentioned in the Annex I PERMENHUB Ship Registration (Article 4 paragraph (1)), with conditions (Article 5 paragraph (2)):

1. Has a gross volume of at least 7 GT (seven gross tonnage);

2. Owned by Indonesian Citizens or Legal Entities established under Indonesian Law and domiciled in Indonesia;

3. Owned by an Indonesian Legal Entity which is a joint venture whose majority shares are owned by Indonesian Citizens.

The binding of objects as collateral must be in a separate agreement, other than the loan agreement. This is because the function of the material collateral binding agreement is different from the debt agreement, the debt agreement functions give birth to rights and obligations related to the provision of debt payments, while the security agreement give birth to the debtor's obligation to submit the object to be secured related to the credit. This is basically why the security agreement was made separate from the debt agreement, but still in one unit. Separate but still a single entity that makes a security agreement called an additional agreement (asesoir), and the loan agreement is referred to as the main agreement (principal).

The existence of a Mortgage security agreement as an addition is to follow the principal agreement, when the principal agreement is deleted, meaning that the debts have been completed, then of course the security agreement will also be removed as well. Whereas when the Mortgage security agreement is abolished, it is not certain that the principal agreement is also deleted, because the security agreement may be 
deleted because the collateral object is executed, and still waiting for payment to pay off the obligation under the principal agreement, or the security agreement may be deleted because the collateral object is lost or destroyed.

In addition to the collateral object must be registered, as one must do procedural for the Mortgage security institution, is the Mortgage security registration. Registration is a way of fulfilling the principle of publicity that must be fulfilled in order to fulfill the legal requirements for the birth of a collateral rights. Ship Mortgage, as confirmed in Article 1179 BW, namely the bookkeeping of all Mortgage bonds must be made in the public registers provided for it, and if not done then a Mortgage will not have any law protection. Ship Mortgages publicity are regulated in Article 60 paragraph (2) of the Shipping Law, which confirms that the registration of ship Mortgage is carried out by the Pejabat Pendaftar Pencatat Baliknama Kapal (P3BK) at the ship registration site. The product issued is a Mortgage Deed which is an authentic deed. Authentic deed is known as a document that has excellent proof of power. ${ }^{7}$ The Ship Mortgage Deed is determined by Article 30 and also Example 10 Attachment II PERMENHUB Ship Registration.

Based on Article 33 paragraph (2) of Government Regulation Number 51 of 2002 concerning Shipping, it is affirmed that the imposition of Mortgages at P3BK must be with documents in the form of:

1. Grosse Deed of registration or renaming of ships;

2. Credit agreement.

Further arrangements regarding technical registration are contained in Article 29-32 PERMENHUB Ship Registration. As a final mechanism, the Mortgage Deed is kept by the P3BK, then P3BK gives a Ship Mortgage Deed Grosse, Ship Registration Deed Grosse, and Ship Name Transfer Deed Grosse to the recipient of the Mortgage (creditor). Thus, several stages of securitying a Ship Mortgage can be briefly described as follows:

\footnotetext{
7 Rahmiah Kadir, 'Pertanggungjawaban Notaris Pada Penerbitan Covernote' (2019) 31 Jurnal Mimbar Hukum < https://journal.ugm.ac.id/jmh/article/view/35274>. [129].
} 
1. Making principal agreements (debts);

2. Making a Mortgage Power of Attorney (SKMH);

3. Mortgage Registration on P3BK.

SKMH is not an obligation in ship Mortgages security, though SKMH is still used in Mortgage security because the substance may give greater law protection to the debtor and creditor, that's why SKMH is still included in one column of Mortgage Deed as an optional.

Registration of a security agreement is essentially intended so that third parties have the opportunity to know that certain objects are bound as collateral for the benefit of certain creditors, for a certain amount, with certain promises. This means that the registration has a consequence to a third party outside the loan agreement with a security. Through the registration of the security agreement, the third party indirectly becomes bound by the loan agreement with the existing collateral, in the form of being deemed to know and obliged to respect the process of the debts that burden the object. So that when a third party carries out a legal act against the object (for example buying), the third party is obliged to carry the risk when the object is executed at any time on the basis of a debt that has matured. This means that a third party will be deemed to have good intentions, when it will do legal actions against an object, it checks first in the registration book or register in the place of the security institution concerned for the type of object, in order to ascertain whether the object of legal action against is not being secured with any security institution.

Legitimation of Mortgage securitys, carry an important meaning, that the creditor can be legally and protected by law, to execute the object of the Mortgage security when the debtor defaults. However, there are quite number of obstacles that arise both when the Mortgaged ship is in the country, or is outside the jurisdiction of Indonesia. In previous studies, the authors found that one way of execution could still be done when the ship was outside the jurisdiction of Indonesia, namely by renewing the regulation of ship Mortgage security accompanied by some substance in the adopted arrangements, as well as professional increase of P3BK. Of course, in addition to this method, other ways to strenghten legal certainty for the creditor to 
be fully repaid must be found, thus the Mortgage security institution still exists as a flexible security institution and is needed by society in the development of this era.

\section{Sister Ship Binding Clause on Ship Mortgage}

Identification of execution obstacles begins at the seizure stage of collateral objects execution, at this stage of seizure cannot be done because of cross-border aspects. The search for a solution needs to be done by comparing the law, which in this case can be done by comparing the law and its practice in the Netherlands, considering that Indonesia inherits several Dutch rules, and the Netherlands also has the same Civil Law legal system. Regarding the execution of secured Mortgage object, there are 3 (three) Conventions that can be used as a legal basis, first is the International Convention on Maritime Liens and Mortgage 1993, the second is the International Convention Relating to the Arrest of Seagoing Ships 1952, and the third is Arrest of Ships 1999.

The Netherlands did not ratify International Convention on Maritime Liens and Mortgage1993, which means that when Mortgaged Indonesian ships sailed and relied on the Netherlands, the Netherlands was free not to recognize Mortgages attached to the ship if it was only guided by the International Convention on Maritime Liens and Mortgage 1993. However, in practice the Dutch state respects Mortgage security that attached to foreign ships that are not part of the European Union on a customary basis, and respects existing international relations or cooperation with the flag state. Nevertheless, the Dutch put forward the certainty of repayment of Mortgage security and/or the fulfillment of other rights attached to the ship with the detention of ships, therefore the Dutch ratified the International Convention Relating to the Arrest of Seagoing Ships (Brussels, 10 May 1952).

The 1952 Arrest of Ships Convention is only valid when a ship detained by a Dutch Arresting Party is a ship that raises the flag of the State which is also a participant in the Convention (including Dutch ships themselves), and is detained for the Maritime Claim, because this Convention is essentially "arresting ship by the judicial process to secure a maritime claim". Conversely, if the detention carried 
out in the Netherlands against a flag hoisting ship is not from the participating country of the Arrest of Ships 1952 Convention, or detained not because of the Maritime Claim, then the Dutch State law is applied. This is as Article 8 of the Arrest of Ships 1952 Convention which confirms that "The Convention shall apply to a Contracting State in the Contracting State of any Contracting State". So when a Dutch State ship is detained by a party from the Netherlands itself on the basis of the Maritime Claim, the 1952 Arrest of Ships Convention is enacted. When the Dutch State ship is detained by the Dutch State itself not because of the Maritime Claim, then the Dutch state's own internal law applies. Likewise, the Indonesian state ship (which does not ratify this Convention) is detained by the Dutch State either because there is or is not a Maritime Claim, the law which is applied is the internal law of the Netherlands. As Gianluca revealed: ${ }^{8}$

"The nationality of the claimant is not a relevant factor in determining whether an arrest is allowed. Dutch ships may be arrested in the Netherlands by claimants domiciled in the Netherlands, for claims of all kinds and irrespective of whether the claims qualify as a maritime claim".

There are 17 (seventeen) types of maritime claims in the 1952 Arrest of Ships Convention which can cause the ship to be detained in the Netherlands. There are also things that are not maritime claims. While some types of claims that are not classified as maritime claims in the Arrest of Ships 1952 Convention are:

1. Outstanding insurance premiums, including calls of P\&I clubs;

2. Claims in respect of a sale and purchase agreement regarding a ship;

3. Oil pollution claims;

4. Broker's commission and probably also claims of stevedores.

In Article 3 of the Arrest of Ships 1952 Convention, the participating countries are allowed to hold the "sister ship" which is a ship that has an identical character with the ship being searched and will be detained, but of course the ship must also be registered in the name of the same owner as the ship being sought and will detained it. In its development there are exceptions as expressed by Steenderen: ${ }^{9}$

\footnotetext{
8 Gianluca Kreuze, Ship Finance in Netherlands (1st edn, Loyen \& Loeff NV 2014).[84].

9 Arnold J van Steenderen, Getting the Deal Through Shipping 2015 - Netherlands (Law Business Research 2015).[145].
} 
"In another judgment the Dutch Supreme Court (9 December 2011) ruled that Article 3 of the Brussels Convention (Arrest of Ships 1952) does not prevent the arrest of a ship of a debtor that not being the owner of the ship to which the maritime claim is related. This would mean, for instance, that an arrest of ships owned by a time charterer based on a claim of charter hire is possible, provided the Brussels Convention (Arrest of Ships 1952) is applicable and other legal requirements for an arrest can be met".

Based on that Jurisprudentie, the Dutch Arresting Party can also hold a ship that is not the property of the debtor, but in certain circumstances as stated above.

When a Dutch Arresting Party holds a ship from a country that is not a participant of the Arrest of Ships 1952 convention, or not because of the Maritime Claim, it is still permissible through the arrangement in Article 267 Book 3 NBW:

"The Mortgage instrument may stipulate that the Hypotheekhouder shall be entitled to take over the management of the Hypotheeken property, if the Hypotheekgever seriously fails in the performance of his obligations owed to him and if the district court judge hearing applications for interim relief grants him authorization to do so. The instrument may also stipulate that the Hypotheekhouder will be entitled to take the thing subject to the Hypotheek under his control if this is required for purposes of the foreclosure. The Hypotheekhouder shall not have these rights, unless they are expressly stipulated".

Creditors of Ship Mortgages security holders in the Netherlands can take over (seize) the Mortgaged ship, when the debtor is unable to carry out his obligations to the creditor, and has been approved by the Court. So in the above provisions, it is permissible for execution seizure. Can also be promised in Ship Mortgage Notarial Deed, that the creditor has the right to control certain objects on the ship (which is also burdened by the ship Mortgage), to support the implementation of the seizure. Both seizure of execution, seizure of security and other procedures related to seizure and execution, are further regulated in Wetboek van Burgerlijke Rechtsvordering or the Dutch Code of Civil Procedure, which is the new Dutch Procedural Law. Also presented by Steenderen: ${ }^{10}$

"The test to be met by the alleged debtor to prove an arrest was wrongful is the test of proving an unlawful act under article 6:162 of the Dutch Civil Code. If

10 ibid. 
the claim for which the arrest was made ultimately fails in the court or arbitral proceedings on the merits, the arrest was wrongful and the arresting party can be held liable for any and all damages and losses".

When the ship is in confiscation, the ship owner remains the responsible party for the maintenance of the ship. In practice, when the seized ship is in the framework of repaying the security on the ship Mortgage, the creditor will automatically ensure with all its efforts to keep the ship safe, maintained, so that the selling price does not decrease. These ship maintenance costs can be claimed at the time of execution, and are ranked under Ship Mortgage security, but are prioritized over other claims.

Based on the above regulation, it can be seen that compared to the arrangement of seizure or detention of ships in Indonesia which must be guided by Rv and there is the Rijdende Beslag principle contained in Articles 577 and $578 \mathrm{Rv}$, in the new Dutch law arrangement, this principle has not been applied well for confiscation using the Arrest of Ships 1952 Convention or using Dutch internal law. Although $\mathrm{Rv}$ is a legal product of Dutch inheritance, but through its development, the Dutch civil procedural law which regulates confiscation (Wetboek van Burgerlijke Rechtsvordering) no longer recognizes this limitation, this is because the Dutch have adjusted the rules of the Arrest of Ships 1952 Convention which has been ratified by the Dutch. Arrangement of Article 3 paragraph (1) of the 1952 Arrest of Ships Convention which become the basis, affirmed:

"Subject to the provisions of para (4) of this article and of article 10, a claimant may arrest either the particular ship in respect of which the maritime claim arose, or any other ship which is owned by the person who was, at the time when the maritime claim arose, the owner of the particular ship, even though the ship arrested be ready to sail; but no ship, other than the particular ship in respect of which the claim arose, may be arrested in respect of any of the maritime claims enumerated in article 1, (o), (p) or (q)".

The article confirms that ships with maritime claims can be withheld, or similar ships (sister ships) can also be detained as long as they are the same owner, even when the ship is ready to sail. But sister ships cannot be detained when not related to ownership disputes, disputes between owners, or Mortgage disputes. The above provisions then become the basis for the provisions in Article 563 paragraph (1) and (2) jo. 564 verse (3) Dutch Wetboek van Burgerlijke Rechtsvordering. 
Based on the discussion above, it can be seen that the embryo of the sister ship utilization as one of the ways to strenghten the legal certainty of the creditor in the case of Mortgage security objects execution when the object is outside Yuirisdiction. Indonesia did not ratify both the Arrest of Ships 1952 Convention and the Arrest of Ships 1999 Convention, but Indonesia ratified the International Convention on Maritime Liens and Mortgage 1993, the regulation of this last mentioned convention may become a starting point for the Indonesian government to regulate the sister ship's binding as an additional security or backup, considering the sister ship arrangement as discussed above is raised from maritime claim, and Mortgage is included in it. When the legislator has not been able to do legal reform for the Ship Mortgage security institution with all the substance that the author has found in his research, or other writers before the author, then the event remains in terms of sister ship implementation, because it is open the possibility to be regulated by the parties through agreement, considering that Indonesia adheres to the freedom of contract principle in Article $1338 \mathrm{BW}$.

An agreement that can be used as a home for the sister ship binding clause in Indonesia Mortgage security is on SKMH. On SKMH there are promises, including the promise to sell on its own power (parate executie). SKMH which until now is only optional, meaning that it is not mandatory, so with the addition of the sister ship clause, the parties are expected to think and understand more the urgency to utilize SKMH in their Mortgage security. The expected clause is that the debtor must at least have a twin ship, of course with the same value as the ship that will be the Mortgage security object. This ship is then bound in an agreement, and is allowed to be used but may not be used to sail across Indonesian jurisdiction as long as the loan and Mortgage security process takes place. Can also be used as a sister ship, is a ship that is still in the stage of development, so that later when the construction of the ship is completed it coincides with the time the debt matured. This is only an additional security object, to be executed when the main ship that is charged with Mortgage securitys is outside the jurisdiction and having difficulty of execution. This is permissible in BW, which is when the Mortgage security 
object cannot be executed, it is permissible to look for other objects with the same value. Regular supervision of sister ship, principles of specialization, principles of publicity, knowledge, cooperation and professionalism of P3BK play an important role in this matter. Although this is a good thing, but for the implementation of the sister ship execution it is certainly not possible to use executive or parate executie titles, so the sale is done privately or under hand. This is because the Mortgage Security Deed Grosse was issued not for the sister ship, but for the main ship which is subjected to Mortgage security.

\section{Conclusion}

Ship Mortgages security institutions in Indonesia are one of the security institutions in Indonesia that are quite popular but still lacking in regulation, these shortcomings actually result in weaknesses in terms of their execution, but are limited to executions carried out when the ship is outside the jurisdiction of Indonesia. One way is to tie the sister ship of the ship that is used as an object of Mortgage security. The practice of sister ship binding has been carried out in the Netherlands, and has even been normalized in a law. Indonesia as the heir of the rule of law from the Netherlands, of course also be able to apply the same thing, considering the legal system is the same. Although Indonesia has not been able to normalize the rules regarding this sister ship, the solution is through an agreement. The sister ship's binding can be done through an agreement, in this case the agreement that can become a home for the sister ship's binding clause is SKMH, thus the parties who plan to utilize Mortgage security institutions will understand more the urgency to make SKMH before registering a Mortgage through P3BK. This sister ship is an additional security, and this is permitted in BW when Mortgage objects cannot be executed, finding other objects with the same value to be executed is allowed. The consequence is that the sister ship can even be executed, but it cannot be executed using executorial or parate executie titles, but through the ordinary sale process, because the Mortgage deed refers to the ship that is subject to Mortgage security, not the sister ship. 


\section{Bibliography}

Anita Afriana and Efa Laela Fakhriah, 'Understanding the Plurality of Consumer Dispute Resolution in Indonesia: A Comparative Study with Singapore' (2019) 34 Jurnal Yuridika <https://e-journal.unair.ac.id/YDK/article/view/9091>.

Arnold J van Steenderen, Getting the Deal Through Shipping 2015 - Netherlands (Law Business Research 2015).

Gabrielia Febrianty Shofiana and Abd. Shomad, 'Transformation of Banking Law in Indonesia' (2019) 19 Jurnal Dinamika Hukum.

Gianluca Kreuze, Ship Finance in Netherlands (1st edn, Loyen \& Loeff NV 2014).

Imeda Tsindeliani, 'Financial Law as a Public Law Branch: A Fresh Look at the Signs of Publicity' (2019) 22 Journal of Legal, Ethical and Regulatory Issues <https://www.abacademies.org/articles/financial-law-as-a-public-lawbranch-a-fresh-look-at-the-signs-of-publicity-8677.html $>$.

Kartini Muljadi and Gunawan Widjaja, Hak Istimewa, Gadai Dan Hipotek (Kencana 2005).

Muhammad Arfin Muhammad Salim, 'Authenticating the Tourist Destination on the Official Tourism Website of Indonesia: A Multimodal Perspective' (2018) VI Astra Salvensis (Supplement no. 1).

Rahmiah Kadir, 'Pertanggungjawaban Notaris Pada Penerbitan Covernote'(2019) 31 Jurnal Mimbar Hukum <https://journal.ugm.ac.id/jmh/article/view/35274>.

Soeling Pantius D, 'Enhancing Regional Competitiveness Through Village Owned Enterprise in East Priangan Indonesia' (2018) VI Astra Salvensis (Supplement no. 1).

HOW TO CITE: Fani Martiawan Kumara Putra, 'Sister Ship Binding Clause as a Reinforcement of Debt Repayment Legal Certainty on Ship Mortgage' (2020) 35 Yuridika. 